\title{
THE LUNDGRENI EXTINCTION EVENT IN CENTRAL ASIA AND ITS BEARING ON GRAPTOLITE BIOCHRONOLOGY WITHIN THE HOMERIAN
}

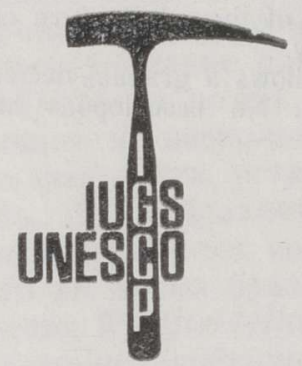

GLOBAL BIOEVENTS

The Homerian pelagic and hemipelagic graptolite sequences are known in many regions of the world. They are the most complete and well studied in Europe, Arctic Canada and South Tien Shan. The graptolite zonations established in these territories are based mainly on the stratigraphical distribution of monograptids. Some plectograptids and cyrtograptids are diagnostic as well. Most of the graptolite biozone associations are uniform over a wide area. There are regional differences, however, in the taxonomic structure of successive associations within some late Homerian intervals. In general the Homerian graptolite development shows different kinds of events such as extinctions, radiations, morphological innovations, and gradual phyletic evolution.

The main lundgreni extinction event has been recognized in the earliest period of the Silurian graptolite studies when the lundgreni, ludensis and nilssoni biozones were established in the Wenlock-Ludlow boundary interval for the first time. E. Wood proposed to draw the series boundary at the base of the ludensis Biozone (=vulgaris, Wood, 1900, p. 422) because of the most dramatic drop in graptolite diversity at the top of the lundgreni Biozone. This event has been used as a biostratigraphical basis for drawing the boundary between lower and upper Silurian at the top of the Wenlock Series.

Until recently biostratigraphical and paleontological data on the postlundgreni graptolites have been scarce. An assumption has been made that this time interval corresponds to the most dramatic evolutionary low in the development of Silurian graptolites. At first the ludensis Biozone, later the nassa (nassa/dubius) and ludensis biozones were the only units recognized within the upper Homerian. Recently valuable new data have been obtained, and a complex picture of the graptolite dynamics became evident (Lenz, 1980; Jaeger, 1989; Корень et al., 1986; Корень, Риненберг, 1988). Recent studies of the upper Wenlock graptolite sequences in the Alai Range, Central Asia, have made an especially important contribution to the problem.

The present paper is based on the studies of pelagic deposits of the Kursala Formation (Wenlock to Pridoli). They form part of the extensive lower Palaeozoic allochthonous suits in the Alai Range, South Tien Shan. The Kursala Formation consists of graptolite-bearing carbonaceous mudstones with subordinated calcareous layers or lenses. The Homerian graptolites collected from seven measured sections are abundant and

* ВСЕГЕИ (All-Union Geological Scientific Research Institute), 199026 Ленинград, Средний пр. 74. 
comparatively well preserved. Correlation within the study area $(100 \mathrm{~km}$ east to west) was carried out on graptolite data combined with the detailed structural mapping.

Presently available biostratigraphical and paleontological data enable to establish in the lower Kursala Formation the following graptolite biozones: lundgreniltestis, nassa/dubius, sherrardae (praedeubeli), deubeli, ludensis, and nilssoni/colonus (Fig. 1). Some zonal boundaries are based on the distinctive changes in graptolite diversity which are expressed in the extinctions, radiations, and population bursts (the nassa/dubius and nilssoni/colonus). The others are defined by the speciation events, namely by the first appearance of the diagnostic monograptid species (the sherrardae, deubeli, and ludensis biozones).

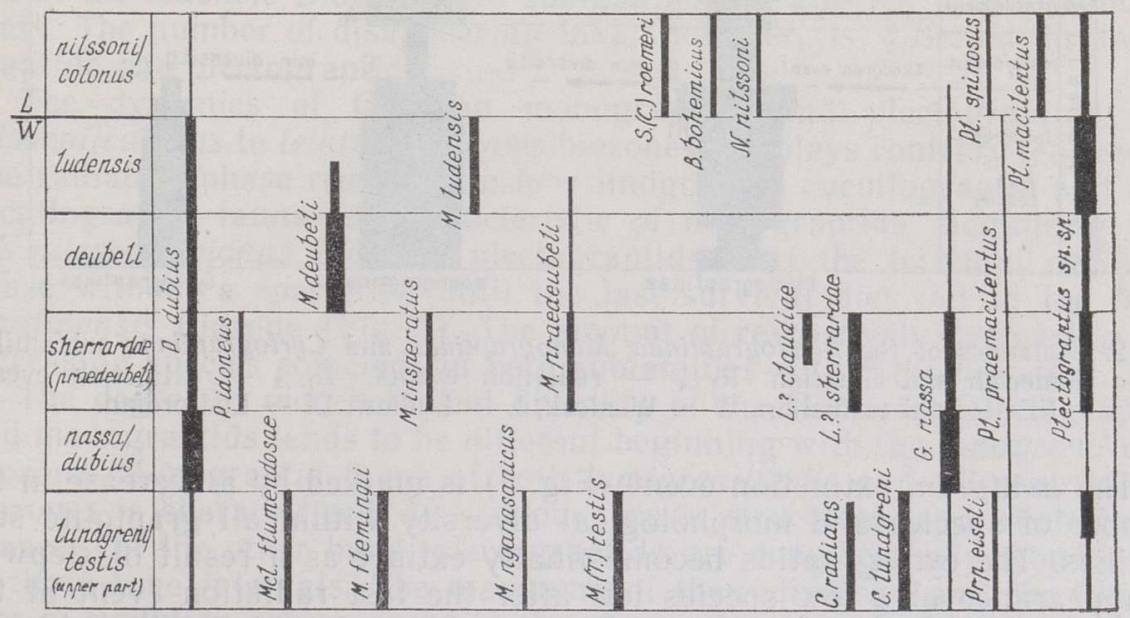

Fig. 1. Vertical distribution of the Homerian monograptids, cyrtograptids and several diagnostic taxa of plectograptids in the lower Kursala Formation, Alai Range, Central Asia.

The graptolite assemblages of the lundgreni/testis and nilssoni/colonus biozones consist of widely distributed diagnostic species. The upper Homerian graptolites are remarkably diverse in Central Asia as compared with those known in the other regions. They include monograptids characteristic of the European, Arctic and Australian sequences. Some species are known only in South Tien Shan. This mixed fauna provides better evidence for interregional zonal correlation. Preliminary identifications of plectograptids made by the present author and H. Jaeger proved their exceptional taxonomic diversity and morphological variety in the sections studied.

The main purpose of the present paper is to demonstrate patterns of the diversity changes within the evolving Homerian subfamilies Plectograptinae, Monograptinae and Cyrtograptinae (Fig. 2). An attempt is made to compare their dynamics within successive zones and to discuss both similarities and differences.

Pre-extinction fauna of the lundgreniltestis Biozone displays different tendencies. Monograptids are morphologically diverse and all genera and species persist till the end of the biozone (Fig. 1). The number of species and morphological diversity of plectograptids increase before the lundgreni extinction event occurs. They are the most scarce and uniform elsewhere. Cyrtograptids diversity is slowly declining towards the top of the lundgreni/testis Biozone (Fig. 2). The pre-extinction fauna has morphological features common with those of the early Silurian graptolites. It inherits theca structures which have been developing since the end of Telychian. 


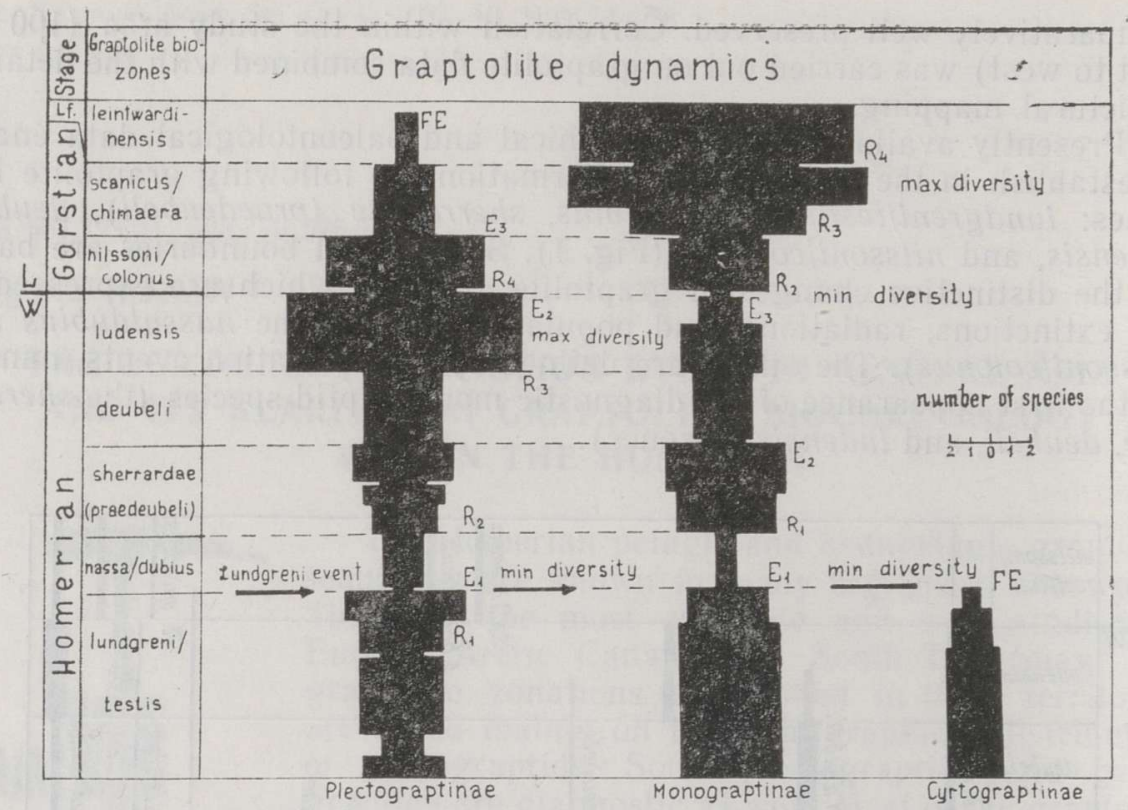

Fig. 2. Dynamics of the Plectograptinae, Monograptinae and Cyrtograptinae subfamilies in the Homerian and Gorstian. $\mathrm{R}_{1 \ldots 4}$ - radiation events, $\mathrm{E}_{1 \ldots 3}$ - extinction events, FE - final extinction, W - Wenlock, L - Ludlow, Lf - Ludfordian.

The lundgreni extinction event (Fig. 2) is marked by a decrease in the number of species and morphological diversity within all graptolite subfamilies. The cyrtograptids become finally extinct as a result of stepwise disappearance of a few species left after the last radiation event at the beginning of the lundgreniltestis Biozone. The most severe diversity fall takes place among monograptids. The long-ranging and conservative Pristiograptus dubius is the only known species surviving the crisis. The comparatively diverse plectograptid fauna becomes suddenly extinct with Plectograptus macilentus being the only survival.

The post-extinction fauna of the late Homerian goes through a number of successive events of short duration. Among them are population bursts in both long-ranging and newly appeared taxa, the introduction of morphological innovations, short periods of single speciations, as well as distinctive increases and decreases in species diversity.

The first post-extinction graptolite association (the nassa/dubius Biozone) is characterized by the lowest diversity known among the Silurian graptolites. It consists of long-ranging Pristiograptus dubius and Plectograptus praemacilentus occurring together with the newly appeared Gothograptus nassa. The population burst of $P$. dubius and $G$. nassa is a shorttime event, globally recognized. In the Kursala Formation the nassa/dubius Biozone is represented by mudstones $(0.2-0.3 \mathrm{~m}$ thick) with their bedding surfaces covered with numerous specimens of both species.

The overlying sherrardae (praedeubeli) Biozone begins with the appearance of several new species, such as Monograptus insperatus, Pristiograptus idoneus, Lobograptus? sherrardae and Monograptus praedeubeli (Fig. 1). The first species with completely developed paired lateral lobes in all thecae is of cryptogenic origin. The others belong to two different phylogenetic lines. Both appear as a result of a short-time radiation event which took place within the ancestral $P$. dubius stock. Plectograptids show a stepwise increase in the taxonomic diversity to the end of the sherrardae (praedeubeli) Biozone. As a result of a speciation event the number of monograptid species is slightly increasing, too. 
Further tendencies of the development of monograptids and plectograptids within the deubeli Biozone are similar. After some extinction and speciation events close to the boundary between the sherrardae (praedeubeli) and deubeli biozones graptolites remain comparatively stable in their taxonomic composition. The deubeli association consists mostly of taxa known in the underlying biozone (Fig. 1).

Since the latest Homerian up to the beginning of Ludfordian, monograptids and plectograptids have different evolutionary scenarios (Fig. 2). In the ludensis Biozone monograptids show stepwise extinction with only one species left to cross the boundary. Plectograptids manifest the contrary tendency. At the beginning of the ludensis Biozone they undergo radiation events in different phylogenetic lines. Their differentiation is based on the introduction of several new morphological structures. At the end of the ludensis Biozone both subfamilies are affected by an extinction event. The number of disappearing taxa, however, is different in monograptids and plectograptids.

The dynamics of Gorstian monograptids and plectograptids (the nilssoni/colonus to leintwardinensis biozones) displays contrary tendencies. The radiation phase resulting in new linograptid, cucullograptid and neocucullograptid faunas is characteristic of monograptids. Beginning with the nilssoni/colonus Biozone, plectograptids start the terminal declining phase without a speciation until the last survival dies out in the leintwardinensis Biozone (Fig. 2). The amount of respectively decreasing and increasing species coincides in both subfamilies within the Gorstian.

The degree of morphological diversity of the Homerian plectograptids and monograptids tends to be different beginning with the lundgreni/testis Biozone. Monograptid fauna of both lundgreni/testis and nilssoni/colonus biozones is characterized by various theca structures and rhabdosome shapes. On the other hand, plectograptids are comparatively monotonous in those time intervals. The maximum of their diversity and the highest rate of evolution are observed in the sherrardae (praedeubeli) and ludensis biozones. They exploit different morphological novelties in the theca and rhabdosome structure. Contemporaneous monograptids beginning with the sherrardae (praedeubeli) Biozone possess one and the same morphotype - paired lateral elevations or lobes on the theca apertures which were suddenly introduced in several phylogenetic lines. The species differentiation is based on the degree of expressivity and penetrance of this character in the astogeny. The morphological diversity within monograptids increases sharply at the beginning of the nilssoni/colonus Biozone after the ludensis extinction event. A new monograptid fauna has been progressively developing until it reaches maximum diversity within the scanicus/chimaera to leintwardinensis biozones.

\section{Conclusions}

The stratigraphical record of Homerian graptolites indicates two shortterm diversity falls. They are the results of the lundgreni and ludensis extinction events. The first one (Fig. 2, $\mathrm{E}_{1}$ ) is more dramatically expressed in the taxonomical and morphological diversity changes. The number of extincted species is comparable within the evolving subfamilies Plectograptinae, Monograptinae and Cyrtograptinae. The second extinction is a short-time and sudden event for the morphologically diverse plectograptids (Fig. 2, $\mathrm{E}_{2}$ ) whereas it is the end of the declining phase in the evolution of comparatively uniform monograptids (Fig. 2, $\mathrm{E}_{3}$ ).

In the time between the two extinctions the morphological diversity and the number of innovation events are reverse for plectograptids and monograptids. Plectograptids undergo several radiation events (Fig. 2, $\mathrm{R}_{2}$ to 
$\mathrm{R}_{4}$ ) before the beginning of the declining phase with final extinction in the late Gorstian to early Ludfordian. The evolution of the post-lundgreni and pre-ludensis monograptids is characterized by the only radiation event (Fig. 2, $\mathrm{R}_{1}$ ) due to the introduction of a single morphological novelty with subsequent insignificant variations of the same feature until an explosive radiation of the new Gorstian fauna occurs (Fig. 2, $R_{2}$ to $R_{4}$ ).

The dynamics of the Homerian and Gorstian graptolites gives rise to an assumption that the Monograptinae and Plectograptinae subfamilies have been ecologically controlled by each other. The loss of species in monograptids has eventually caused an increase in the amount of species in plectograptids.

\section{REFERENCES}

Jaeger, $H$. Graptolite faunal turnover and the revised graptolite zonation across the Wenlock-Ludlow boundary. -- The Murchison Symposium. An International Symposium on the Silurian System. Programme and Abstracts. University of Keele, U.K. 1989, 49-50.

Lenz, A. C. Wenlockian graptolite reference section, Clearwater Creek, Nahanni National Park, Northwest Territories, Canada. - Can. J. Earth Sci., 1980, 17, N 8, $1075-1086$.

Wood, E. M. R. The Lower Ludlow formation and its graptolite fauna. - Quart. J. Geol. Soc. Lond., 1900, 56, 415-492.

Корень Т. Н., Клишевич В. Л., Риненберг Р. Е. Опорный разрез силурийских и нижнедевонских пелагических отложений Южной Ферганы. - Сов. геология, 1986, № $11,62-74$.

Корень T. Н., Риненберг P. E. Событие lundgreni в поздневенлокских пелагических фациях в Южном Тянь-Шане. - In: Граптолиты в истории земли. Тезисы докл. 5 симп. по изучению граптолитов СССР. Вильнюс, 1988, 11.

Presented by D. Kaljo

Received

Nov. 11, 1990

\section{Tatjana KOREN}

\section{VÄLJASUREMISSUNDMUS LUNDGRENI KESK-AASIAS JA SELLE TÄHENDUS HOMERIANI GRAPTOLIITSELE BIOKRONOLOOGIALE}

Wenlocki ja Ludlow' piirikihtides on eraldatud järgmised graptoliiditsoonid: lundgreniltestis, nassaldubius, sherrardae (praedeubeli), deubeli, ludensis, nilssoni/colonus. On analüüsitud mono-, cyrto- ja plectograptiidide taksonoomilise koosseisu ja morfoloogilise mitmekesisuse mutumist enne ja pärast massilist väljasuremist lundgreni tsooni lõpul. Sel ajal kaovad cyrtograptiidid, Homeriani lõpul plectograptiidide mitmekesisus ja arvukus kasvavad, monograptiidide puhul aga kahanevad, Ludlow' alguses muutuvad protsessid vastupidiseks.

\section{Татьяна КОРЕНЬ}

\section{СОБЫТИЕ ВЫМИРАНИЯ LUNDGRENI В СРЕДНЕЙ АЗИИ И ЗНАЧЕНИЕ ЕГО ДЛЯ БИОХРОНОЛОГИИ ГОМЕРА ПО ГРАПТОЛИТАМ}

В непрерывных разрезах пограничных отложений венлока и лудлова выделены шесть граптолитовых биозон - lundgreniltestis, nassa/dubius, sherrardae (praedeubeli), deubeli, ludensis, nilssoni/colonus. В пределах этой зональной последовательности проанализирована динамика моно-, цирто- и плектограптид. Обсуждены изменения таксономического состава и морфологическое разнообразие представителей различных подсемейств до и после их массового вымирания в зоне lundgreni. Выявлены общие закономерности, а также различия в последовательности и масштабах вымирания, радиации и морфологических новаций. 